\title{
Studi Korelasi Pola Asuh, Religiusitas dengan Impulse Buying pada Mahasiswa Universitas Islam Bandung
}

\author{
Rozana, Eni Nuraeni Nugrahawati, Dinda Dwarawati \\ Universitas Islam Bandung, Jl. Tamansari No. 1 Bandung \\ e-mail: anna.dyreza93@gmail.com
}

\begin{abstract}
This research aims to study about correlation between parenting, religiusity and impulse buying among Bandung Islamic University students who join pesantren for bachelor candidate. This research used correlation research design involving 420 students of Bandung Islamic University who join pesantren for bachelor candidates of 2016. Subjects are between 18-21 years old from some faculties which are engineering, science, dakwah, communication, teacher training, ekonomics, law, syariah and psychology. Result shows that 328 students are in impulse buying category. However, parenting and religiusity are not significant variables effecting impulse buying phenomena. Further research suggested to deepen parenting variable since related to impulse buying behaviour.
\end{abstract}

Keywords: correlation, parenting, religiusity, impulse buying

\begin{abstract}
Abstrak
Penelitian ini bertujuan untuk melihat hubungan antara pola asuh, religiusitas dengan impulse buying pada mahasiswa peserta pesantren calon sarjana di UNISBA. Penelitian ini menggunakan design korelasidengan melibatkan 420 mahasiswa Universitas Islam Bandung yang mengikuti Pesantren Calon Sarjana tahun 2016. Subjek berusia 18-21 tahun dari fakultas teknik, MIPA, dakwah, komunikasi, tarbiyah, ekonomi, hukum, syariah dan psikologi. Hasil penelitian menunjukkan 328 mahasiswa masuk dalam kategori impulse buying. Namun ketika dilihat secara keseluruhan tampak bahwa variable pola asuh dan religiusitas bukan merupakan variable yang secara signifikan berpengaruh pada munculnya perilaku impulse buying. Penelitian selanjutnya diperlukan upaya memperdalam variabel pola asuh terkait dengan kemunculan perilaku impulse buying.
\end{abstract}

Kata Kunci: hubungan, pola asuh, religiusitas, impulse buying

\section{Pendahuluan}

Setiap orang memiliki kebutuhan masing-masing yang mana mereka mempunyai cara tersendiri untuk memenuhi kebutuhannya tersebut. Berbelanja adalah suatu kegiatan yang dilakukan oleh seseorang untuk dapat memenuhi kebutuhannya. Idealnya setiap orang berbelanja sesuai kebutuhannya, namun pada kenyataannya banyak orang yang berbelanja tidak berdasarkan pada kebutuhan, melainkan berdasarkan keinginan yang bisa muncul tiba-tiba secara tidak terencana. Hal ini bisa terjadi pada setiap orang terutama pada kebanyakan remaja, karena karakteristik masa remaja yang masih mudah dipengaruhi oleh lingkungan, namun tidak terkecuali juga pada orang dewasa yang idealnya sudah matang.

Usia dewasa merupakan peralihan dari masa remaja akhir menuju dewasa awal. Pada usia dewasa, diharapkan remaja mengalami perubahan ke arah yang lebih matang dalam hal sikap dan perilakunya. Usia dewasa umumnya diidentikkan dengan kemandirian dalam mengambil keputusan, tumbuhnya keinginan untuk mapan dalam hal perekonomian, dan perencanaan untuk masa depan. Saat ini, perkembangan ekonomi yang pesat, berdampak pada kreativitas para produsen dalam menyediakan produk untuk berbagai kebutuhan. Selain produk yang beragam, 
produsen pun menerapkan strategi pemasaran yang tepat, sehingga pembelanjaan spontan sangat mungkin dilakukan ketika melihat barang yang menarik.

Pembelanjaan spontan tersebut dapat dilakukan oleh berbagai kalangan usia mulai anak-anak hingga dewasa. Seperti halnya pada mahasiswa, mahasiswa yang baru memasuki perkuliahan berada pada tahap perkembangan remaja. Pada usia ini mereka mudah dipengaruhi oleh lingkungan, misalnya saat pengambilan keputusan baik pada permasalahan perkuliahan seperti mata kuliah yang akan dikontrak ataupun masalah-masalah yang tidak berhubungan dengan perkuliahan. Seiring dengan waktu, mereka akan beranjak pada tahap dewasa awal yang ditandai dengan adanya tugas perkembangan untuk mandiri dan bertanggung jawab. Mandiri dalam hal mengambil keputusan serta bertanggung jawab terhadap keputusan yang diambilnya dengan pertimbangan yang matang.

Apabila mencermati kebutuhan mahasiswa tentunya akan banyak berkaitan dengan kegiatan mereka dalam perkuliahan, seperti membeli buku literatur, penyediaan alat-alat kegiatan praktikum atau kebutuhan untuk melakukan penelitian. Namun demikian pada kenyataannya, mahasiswa tidak hanya mengeluarkan uang untuk kebutuhan perkuliahan semata. Mereka menghabiskan sebagian uangnya untuk membeli sesuatu yang tidak direncanakan, tidak berhubungan dengan perkuliahan, bahkan membeli barang yang bukan kebutuhan. Semakin sering mereka berbelanja tanpa jelas tujuannya, membuat mereka tidak bisa mengingat barang yang sudah mereka miliki, bahkan mereka kebingungan untuk menyimpan barang-barang yang mereka beli.

Selain itu juga beberapa dari mereka lebih memprioritaskan membeli barang yang hanya mereka inginkan, sehingga kebutuhan untuk mendukung perkuliahan menjadi kurang diperhatikan. Pembelian tersebut terjadi karena dipengaruhi oleh berbagai faktor, antara lain: program promosi, kehadiran sales promotion girl (SPG) atau sales promotion boy, merchandising (pengaturan letak produk) dan packaging (kemasan yang membungkus produk). Bahkan saat ini maraknya situs belanja on-line, semakin memfasilitasi individu untuk membeli. Perilaku mereka akhirnya menjadi gaya hidup yang bisa menjadi masalah jika tidak diatasi.

Kegiatan belanja yang hanya didominasi emosi yang dilakukan secara impulsif disebut sebagai impulse buying. Impulse buying pada dasarnya sama dengan unplanned buying, yaitu dijelaskan sebagai pembelian dimana pembeli membuat pembelian yang tidak direncanakan (Stern, 1962 dalam www.pustaka.unpad.ac.id).

Dittmar dan Drury (2000) menyatakan bahwa impulse buying dapat menjadi berlebihan. Menurut O'Guinn dan Faber (1989), perilaku impulse buying yang berlebihan dapat mengarah pada indikasi patologis, yaitu gangguan compulsive buying. Penelitian yang berkaitan dengan gangguan compulsive buying, menemukan adanya kontribusi pola asuh pada kemunculan compulsive buying. Temuan tersebut muncul saat pemberian intervensi konseling kelompok pada peningkatan selfregulation bagi penderita compulsive buying. Hampir semua subjek penelitian, menyatakan bahwa orang tua sebagai significant person memberikan model bahwa berbelanja dijadikan upaya untuk menghindar dari masalah dan menghilangkan stres (Dwarawati, 2015). Pola asuh orang tua merupakan segala bentuk dan proses interaksi yang terjadi antara orang tua dan anak yang merupakan pola pengasuhan tertentu dalam keluarga yang akan memberi pengaruh terhadap perkembangan kepribadian anak (Baumrind dalam Sigelman, 2003). Selanjutnya orang tua juga merupakan figur yang berperan penting dalam menanamkan nilai-nilai religi kepada seorang anak. Kadar ke- 
terikatan religius seseorang terhadap agamanya disebut religiusitas. Terdapat penelitian terdahulu mengenai impulse buying yang menyimpulkan adanya korelasi antara perilaku impulse buying dengan religiusitas (Nugrahawati, 2014). Penelitian tersebut dilakukan pada mahasiswa kedokteran UNISBA yang sedang mengikuti Pesantren Calon Sarjana. Beberapa temuan dari mahasiswa kedokteran tersebut yaitu bahwa semakin tinggi tingkat ekonomi mereka, maka semakin memberikan kontribusi pada perilaku impulse buying. Seperti misalnya pemberian uang saku di atas Rp. 1.100.000,-, atau fasilitas dari orang tua yang menyediakan kendaraan pribadi untuk pergi kuliah. Dengan demikian dapat dilihat bahwa pola asuh dari orang tua tampak membuat mahasiswa kedokteran menjadi terfasilitasi untuk membeli secara berlebihan.

Tujuan umum dari penelitian ini adalah untuk memperoleh data empirik mengenai keeratan hubungan antara pola asuh, religiusitas dan impulse buying pada mahasiswa peserta Pesantren Calon Sarjana di Universitas Islam Bandung. Mahasiswa UNISBA dibekali mata kuliah Pendidikan Agama Islam selama tujuh semester dengan harapan nilai-nilai religi dapat semakin terinternalisasi pada kehidupan mereka. Asumsinya bahwa orang tua di rumah sudah terlebih dahulu menanamkan nilainilai moral kehidupan melalui interaksi yang terjadi, atau pembelajaran secara langsung dengan kata lain melalui pola asuh yang diterapkan. Oleh karena itu perlu dilihat bagaimana hubungan antara pola asuh, religiusitas dengan impulse buying. Dengan demikian akan diperoleh gambaran mengenai bagaimana pola asuh memberikan kontribusi pada religiusitas dan selanjutnya pada munculnya perilaku impulse buying. Dengan mendapatkan pengetahuan hubungan pada ketiga variabel tersebut, dapat dijadikan sebagai upaya tindakan preventif, sehingga anak-anak akan terhindar dari perilaku impulse buying didukung dengan religiusitas yang tinggi. Hasilnya dapat digunakan oleh bagian kemahasiswaan, dosen wali, terlebih oleh orang tua.

\section{Pola Asuh}

Pola asuh orang tua merupakan segala bentuk dan proses interaksi yang terjadi antara orang tua dan anak yang merupakan pola pengasuhan tertentu dalam keluarga yang akan memberi pengaruh terhadap perkembangan kepribadian anak (Baumrind dalam Sigelman, 2003).

\section{Dimensi Pola Asuh}

Baumrind (dalam Sigelman, 2003) menyatakan bahwa pola asuh terbentuk dari adanya dua dimensi pola asuh, yaitu: 1). Acceptance/Responsiveness/Warm; menggambarkan bagaimana orang tua berrespon kepada anaknya, berkaitan dengan kehangatan dan dukungan orang tua. Mengacu pada beberapa aspek, yakni: sejauhmana orang tua mendukung dan peka terhadap kebutuhan anak-anaknya, peka terhadap emosi anak, memperhatikan kesejahteraan anak, bersedia meluangkan waktu dan melakukan kegiatan bersama, serta bersedia untuk memberikan kasih sayang dan pujian saat anak-anak mereka berprestasi atau memenuhi harapan mereka, dapat menerima kondisi anak. Orang tua yang responsif, penuh kasih sayang dan sering tersenyum, memberi pujian, dan mendorong anak-anak mereka. Mereka juga membiarkan anak-anak mereka tahu ketika mereka nakal atau berbuat salah. Sebaliknya orang tua yang kurang menerima dan kurang responsif sering kali cepat mengkritik, merendahkan, menghukum, atau mengabaikan anak-anak mereka dan jarang mengkomunikasikan kepada anak-anak bahwa mereka dicintai dan dihargai. 2). Demandingness/Control; menggambarkan bagaimana standar yang ditetapkan oleh orang tua bagi anak, berkaitan dengan kontrol perilaku dari orang tua. Dimensi ini mengacu pada beberapa aspek yakni: pembatasan; orang 
tua membatasi tingkah laku anak, menentukan hal-hal yang harus dilakukan anak dan memberikan batasan terhadap halhal yang ingin dilakukan anak. Tuntutan; agar anak memenuhi aturan, sikap, tingkah laku dan tanggung jawab sosial sesuai dengan standar yang berlaku sesuai keinginan orang tua. Sikap ketat; berkaitan dengan sikap orang tua yang ketat dan tegas dalam menjaga agar anak memenuhi aturan dan tuntutan mereka. Orang tua tidak menghendaki anak membantah atau mengajukan keberatan terhadap peraturan yang telah ditentukan. Campur tangan; tidak adanya kebebasan bertingkah laku yang diberikan orang tua kepada anaknya. Orang tua selalu turut campur dalam keputusan, rencana dan relasi anak, orang tua tidak melibatkan anak dalam membuat keputusan tersebut, orang tua beranggapan apa yang mereka putuskan untuk anak adalah yang terbaik dan benar untuk anak. Kekuasaan sewenang-wenang; menggambarkan bahwa orang tua menerapkan kendali yang ketat, kekuasaan terletak mutlak pada orang tua. Mengendalikan atau menuntut aturan yang ditetapkan orang tua, mengharapkan anak-anak mereka untuk mengikuti mereka, dan memantau anakanak mereka dengan ketat untuk memastikan bahwa aturan-aturan dipatuhi. Orangtua yang kurang dalam pengendalian atau menuntut (sering disebut orang tua permisif) membuat tuntutan yang lebih sedikit dan memungkinkan anak-anak mereka memiliki banyak kebebasan dalam mengeksplorasi lingkungan, mengungkapkan pendapat dan emosi mereka, dan membuat keputusan tentang kegiatan mereka sendiri.

\section{Jenis-Jenis Pola Asuh}

Berdasarkan hasil penelitian Baumrind (dalam Sigelman, 2003) di-katakan terdapat 3 jenis pola asuh yaitu: 1). authoritarian: pola asuh ini meng-kombinasikan tingginya demanding-ness/control dan rendahnya acceptancel responsive. Orang tua memaksakan banyak peraturan, meng- harapkan kepatuhan yang ketat, jarang menjelaskan mengapa anak harus memenuhi peraturan-peraturan tersebut, dan biasanya mengandalkan taktik kekuasaan seperti hukuman fisik untuk memenuhi kebutuhannya. 2). authoritative: orang tua authoritative lebih fleksibel; mereka mengendalikan dan menggunakan kontrol, tetapi mereka juga menerima dan responsif. Seimbang dalam kedua dimensi baik demandingness/control maupun acceptance/responsive. Mereka membuat peraturan yang jelas dan secara konsisten melakukannya, mereka juga menjelaskan rasionalisasi dari peraturan mereka dan pembatasannya. Mereka juga responsif pada kebutuhan anak-anak mereka dan sudut pandang anak, serta melibatkan anak dalam pengambilan keputusan keluarga. Mereka dapat diterima secara rasional dan demokratis dalam pendekatan mereka, meski dalam hal ini jelas mereka berkuasa, tetapi mereka berkomunikasi secara hormat dengan anak-anak mereka. 3). Permissive: pola pengasuhan ini mengandung demandingness/control yang rendah dan acceptance/responsive yang tinggi. Orang tua permisif tergolong penyabar, mereka membuat beberapa pengendalian pada anak-anak untuk berperilaku matang, mendorong anak untuk mengekspresikan perasaan dan dorongan mereka dan jarang menggunakan kontrol pada prilaku mereka. Selanjutnya Maccoby dan Martin menambahkan satu jenis pola asuh lagi yaitu pola asuh uninvolved/neglectful: merupakan orang tua yang mengkombinasikan rendahnya demandingness/ control dan acceptance/responsive yang rendah pula. Secara relatif tidak melibatkan diri pada pengasuhan anak mereka, terlihat tidak terlalu peduli pada anak-anak mereka dan bahkan mungkin menolak mereka atau yang lainnya, mereka kewalahan dengan masalah-masalah mereka sendiri yang mana mereka tidak dapat memberikan energi yang cukup untuk menetapkan dan menegakkan aturan. 
Faktor-faktor yang Mempengaruhi Pola Asuh

Darling (1999) mengemukakan ada tiga faktor yang mempengaruhi pola asuh, yaitu: jenis kelamin anak, kebudayaan, dan kelas sosial ekonomi.

\section{Religiusitas}

Religiusitas berkaitan erat dengan agama. Agama berkaitan dengan usahausaha manusia untuk mengukur dalamnya makna dari keberadaan diri sendiri dan keberadaan alam semesta. Selain itu agama dapat membangkitkan kebahagiaan batin yang paling sempurna dan juga perasaan takut. Meskipun perhatian tertuju pada adanya suatu dunia yang tidak dapat dilihat, namun agama melibatkan dirinya dalam masalah-masalah kehidupan sehari-hari di dunia. Agama dimaknai sebagai hubungan antara manusia dengan Tuhannya yang terwujud dalam sikap batin, ibadah dan sikap kesehariannya. Selanjutnya Glock dan Stark (dalam Ancok dan Suroso, 1995) menyatakan bahwa agama adalah sistem simbol, sistem keyakinan, sistem nilai dan sistem perilaku yang terlembagakan. Semua sistem tersebut dihayati sebagai sesuatu yang bermakna.

Selain itu Glock dan Stark (dalam Ancok dan Suroso, 1995) mengemukakan bahwa religiusitas adalah kadar keterikatan religius seseorang terhadap agamanya. Diwujudkannya keberagamaan tersebut dalam perilaku beribadah maupun aktivitas lain dalam kehidupannya. Perilaku tersebut meliputi perilaku yang dapat dilihat maupun tidak dapat dilihat yaitu terjadi di dalam hati manusia. Hal inilah yang menunjukan ketaatan individu tersebut terhadap agamanya. Definisi religiusitas dalam penelitian ini mengacu pada definisi yang dikemukakan oleh Glock dan Stark (dalam Ancok dan Suroso, 1995) yaitu kadar keterikatan religius seseorang terhadap agamanya, dalam hal ini agama Islam.

Menurut Glock dan Stark (dalam Ancok dan Suroso, 1995) terdapat lima dimensi religiusitas, yaitui: 1). Religious belief (dimensi ideologis), dimensi ini menunjukan bagian religiusitas yang berkaitan dengan apa yang harus dipercayai termasuk dalam dimensi ideologis. Kepercayaan dan dokrin agama adalah dimensi yang paling dasar. Inilah yang membedakan satu agama dengan agama lainnya, bahkan satu mazhab dalam satu agama dengan mazhab lainnya. Terdapat tiga kategori kepercayaan. Pertama, kepercayaan yang menjadi dasar esensial suatu agama (Orthodoxy index). Misalnya kepercayaan kepada Nabi Muhammad SAW. Kedua, kepercayaan yang berkaitan dengan tujuan Ilahi dalam penciptaan manusia (Particularism index). Al-Quran menyatakan: "Dialah yang menciptakan kematian dan kehidupan untuk menguji kamu sekalian, siapa diantara kamu yang paling baik amalnya”. (QS. Al-Mulk, 67: 72). Ketiga, kepercayaan yang berkaitan dengan cara terbaik untuk menjalankan tujuan Ilahi di atas (Ethicalism index). Orang Islam percaya bahwa untuk beramal shaleh, ia harus melakukan pengabdian kepada Allah dan pengkhidmatan kepada sesama manusia. 2). Religious practice (dimensi ritual), dimensi ini menunjukan perilaku yang diharapkan seseorang yang menyatakan kepercayaannya pada agama tertentu. Perilaku yang dimaksud bukanlah perilaku umum yang dipengaruhi keimanan seseorang, melainkan mengacu pada perilaku khusus yang ditetapkan oleh agama seperti tata cara ibadah, misalnya tata cara berpuasa. Sholat menghadap kiblat beserta ruku' dan sujud adalah dimensi ritualistik Islam. 3). Religious feeling (dimensi eksperiensial), dimensi ini berkaitan dengan perasaan keagamaan yang dialami oleh penganut agama. Psikologi menamainya sebagai religious experience. Pengalaman agama ini bisa saja terjadi sangat moderat, seperti kekhusyuan dalam sholat atau sangat intens yang dialami oleh para sufi. Kebanyakan agama timur seperti Hindu dan Budha menekankan dimensi mistikal ini. Selanjutnya ia mengalami 
ketenangan batin dan menemukan makna hidup. 4). Religious knowledge (dimensi intelektual), dimensi ini memperhatikan informasi yang dimiliki seseorang tentang kepercayaannya sebagai perbandingan terhadap keimanan yang dimilikinya. Contohnya Ilmu Fiqih dalam Islam yang menghimpun informasi tentang fatwa ulama berkenaan dengan pelaksanaan ritusritus keagamaan. Religious knowledge ini termasuk sikap seseorang dalam menerima atau menilai ajaran agamanya berkaitan erat dengan pengetahuan agama yang dimilikinya, terbuka atau tertutupnya seseorang terhadap hal-hal yang berlawanan dengan keyakinannya. 5). Religious effect (dimensi konsekuensial), dimensi konsekuensial menunjukan akibat ajaran agama dalam perilaku umum, yang secara tidak langsung maupun khusus ditetapkan agama (seperti dalam dimensi ritualistik). Inilah efek ajaran agama pada perilaku individu dalam kehidupannya sehari-hari, baik dalam kehidupan pribadi maupun kehidupan sosial. Contohnya sabar dalam menghadapi persoalan hidup dan berakhlak baik kepada sesama.

Lima faktor tersebut tidak sepenuhnya independen satu sama lain. Pada dasarnya faktor-faktor tersebut saling berkorelasi satu sama lain. Dengan demikian orang yang memiliki kepercayaan yang kuat mungkin saja (tetapi tidak harus) memiliki perasaan religiusitas dan melaksanakan praktik-praktik agama. Se-mentara itu Islam memberikan perspektif sendiri tentang religiusitas. Glock dan Stark (dalam Ancok dan Suroso, 1995) pada dasarnya mencoba melihat religiusitas seseorang bukan hanya dari satu atau dua dimensi, tapi mencoba memperhatikan segala dimensi. Religiusitas dalam Islam bukan hanya diwujudkan dalam bentuk ibadah ritual saja, tetapi juga dalam aktivitasaktivitas lainnya. Sebagai suatu sistem yang menyeluruh, Islam mendorong pemeluknya untuk beragama secara menyeluruh pula. Oleh karena itu hanya konsep yang mampu memberi kemenye-luruhan yang mampu memahami kebera-gamaan umat Islam.

\section{Impulse Buying}

Impulse buying dapat diartikan sebagai suatu perilaku pembelian yang tidak terencana dan spontan, yang dilakukan langsung di tempat, diikuti oleh keinginan kuat dan perasaan nikmat dan senang (Rook, 1987). Dalam pandangan Engel dan Blackwell (1995), perilaku tersebut dinyatakan sebagai suatu perilaku pembelian yang muncul tanpa dilandasi oleh adanya kebutuhan serta rencana pembelian yang terarah. Artinya perilaku tersebut dapat muncul secara spontan, belum tentu dilandasi oleh adanya kebutuhan serta proses terjadinya tidak diikuti oleh tahapan-tahapan seperti halnya proses pembelian model umum yang ada. Meski dilakukan secara spontan, Rook (1987) menjelaskan bahwa ada perasaanperasaan yang menyertainya setelah perilaku tersebut dilakukan, yakni senang dan nikmat diikuti puas yang sifatnya sesaat.

Lebih lanjut Rook (1987) menjelaskan adanya karakteristik dari impulse buying, yaitu: 1). spontanitas, 2). merupakan kekuatan, dorongan/tekanan, dan timbul perasaan yang hebat, 3). munculnya perasaan senang dan terangsang, 4). adanya pengabaian terhadap konsekuensi yang akan diterima.

Dengan pemahaman akan karakteristik dari perilaku tersebut, maka apa yang ditampilkan oleh konsumen saat melakukan proses pembelian tersebut pada akhirnya lebih banyak diwarnai oleh bekerjanya variabel-variabel emosi atau perasaan yang muncul secara tiba-tiba dalam dirinya dan dilandasi oleh kekuatan dorongan yang muncul. Situasi tersebut oleh Rook (1987) digambarkan sebagai berikut "Impulse buying occurs when a consumer experiences a sudden, often powerfull and persistent urge to buy something immediately". Dalam konteks yang lebih spesifik, impulse buying dapat di- 
identifikasikan sebagai tipe perilaku psikologis khusus yang berbeda secara signifikan dari bentuk keputusan membeli konsumen yang bersifat umum atau normal.

Verplanken dan Herabadi (2001) mencoba untuk memetakan perilaku tersebut sebagai suatu konsep perilaku yang dapat dikenali melalui dua elemen, yakni kognisi dan emosi. Bila mengacu pada faktor-faktor yang dapat mempengaruhi munculnya impulse buying, maka Loudon dan Bitta (1993) menemukan hal-hal berikut ini dapat dipandang sebagai faktorfaktor tersebut, yakni: 1). karakteristik produk, 2). faktor marketing, 3). karakteristik konsumen, antara lain kepribadian konsumen, demografis; karakteristik demografis terdiri atas jenis kelamin, usia, status perkawinan, penghasilan, pekerjaan, dan pendidikan dan karakteristik sosio-ekonomi yang dihubungkan dengan tingkat impulse buying.

\section{Metode Penelitian}

Penelitian ini dilakukan dalam rangka melihat hubungan antara pola asuh, religiusitas dengan impulse buying pada mahasiswa Universitas Islam Bandung. Populasi penelitian ini mahasiswa Universitas Islam Bandung yang mengikuti Pesantren Calon Sarjana tahun 2016 yang berusia 20 - 25 tahun berjumlah 420 orang. Adapun pengambilan data dilakukan pada tanggal 20 - 22 juni 2016 bertempat di Kampus II Ciburial.

Penelitian ini dilakukan dengan menggunakan metode penelitian kuantitatif. Pengumpulan data dilakukan menggunakan alat ukur berupa kuesioner yang mengukur pola asuh yang diturunkan dari konsep teori Baumrind (dalam Sigelman, 2003), kuesioner religiusitas yang diturunkan dari konsep teori Glock dan Stark (dalam Ancok dan Suroso, 1995) serta kuesioner impulse buying yang diturunkan dari konsep teori Rook (1987). Adapun alat ukur religiusitas dan impulse buying menggunakan kuesioner dalam penelitian sebelumnya oleh Nugrahawati (2014).
Selanjutnya data dianalisis secara kuantitatif berdasarkan metode analisis korelasi untuk menjawab pertanyaan penelitian. Untuk mengetahui hubungan pola asuh, religiusitas dengan perilaku impulsive buying digunakan suatu metode statistika yaitu Structural Equitions Modeling (SEM) dengan menggunakan program Anos.

Adapun Hipotesis Penelitian "Terdapat hubungan yang erat antara impulse buying, religiusitas dan pola asuh pada mahasiswa Universitas Islam Bandung”.

\section{Hasil Penelitian dan Pembahasan}

Subjek penelitian ini adalah mahasiswa Universitas Islam Bandung yang mengikuti Pesantren Calon Sarjana tahun 2016 yang berusia 20 - 25 tahun yang berjumlah 420 orang dari Fakultas Teknik, MIPA, Dakwah, Komunikasi, Tarbiyah, Ekonomi, Hukum, Syari'ah dan Psikologi. Pengambilan data dilakukan pada tanggal 20 - 22 juni 2016 bertempat di Kampus II Ciburial. Kemudian dipilih yang memenuhi syarat yaitu yang memiliki nilai impulse buying di atas skor 88. Jumlah subjek penelitian yang datanya diolah menjadi 328 orang. Adapun data dari subjek penelitian adalah sebagai berikut: dari data demografi subjek penelitian, diperoleh hasil bahwa 76\% mahasiswa masih tinggal dengan orang tua, artinya bahwa orang tua akan mudah memantau kebutuhan anak-anak baik terkait dengan kebutuhan perkuliahan maupun kebutuhan pribadi. Besarnya uang saku yang subjek peroleh dalam waktu satu bulan, diperoleh data $42 \%$ mendapatkan uang saku kurang dari 1 juta, $49 \%$ mendapatkan uang saku antara 1 - 2 juta, dan $9 \%$ mendapatkan uang saku lebih dari 3 juta. Untuk keperluan transportasi mereka sehari-hari sebanyak $70 \%$ menggunakan motor, selebihnya menggunakan mobil dan angkutan umum. Untuk data kegiatan berbelanja, sebanyak $91 \%$ subjek melakukan aktivitas berbelanja ke mall 1 - 2 kali seminggu, dengan persentase $42 \%$ membeli pakaian dan $54 \%$ membeli makanan, 
sisanya lain-lain. Adapun untuk data banyaknya uang yang habis selama satu minggu sebanyak 33\% < Rp. 300.000,-, 42\% Rp. 300.000,- s.d Rp. 600.000,-, $19 \%$ Rp. 600.000,- s.d Rp. 800.000,- dan 6\% lebih dari Rp. 800.000,-. Untuk penanaman agama 53\% diberikan oleh orang tua, 30\% di tempat yang khusus mengajarkan agama, $11 \%$ di sekolah dan selebihnya mencari sendiri. Untuk konsistensi mempelajari agama, 52\% kadang-kadang mempelajari agama, 28\% belajar dengan kelompok, $14 \%$ masih aktif mengaji dan $4,7 \%$ tidak pernah belajar agama.

\section{Hasil Uji Statistik}

Hasil Uji Kecocokan. Uji kecocokan dilakukan untuk memeriksa tingkat kecocokan antara data dengan model, validitas dan reliabilitas model pengukuran, dan signifikansi koefisien-koefisien dari model struktural. Uji kecocokan dilakukan melalui beberapa tahap yaitu kecocokan keseluruhan model, kecocokan model pengukuran dan kecocokan model struktural.

\section{Kecocokan Model Pengukuran} (Measurement Model Fit). Kecocokan model pengukuran dilakukan terhadap setiap konstruk (hubungan antara variabel laten dengan beberapa variabel teramati/indikator) secara terpisah melalui evaluasi terhadap validitas model pengukuran dan evaluasi terhadap reliabilitas dari model pengukuran.

Variabel Pola Asuh. Model pengukuran pada konstruk pola asuh dilakukan dengan mengukur indikatorindikatornya. Loading factors pada indikator harus lebih besar dari 0.5, karena loading factors indikator yang tinggi mengindikasikan indikator-indikator berkumpul pada variabel yang sama, dan menandakan indikator tersebut valid dan dapat membentuk variabel.

Berdasarkan pengukuran diketahui semua nilai standardized loading factors $(\Lambda)$ untuk masing-masing indikator lebih dari 0.5 sehingga dapat dikatakan bahwa indikator-indikator tersebut memiliki validitas yang baik dalam mengukur variabel pola asuh.

Pengujian reliabilitas ditunjukan oleh nilai construct reliability $(\mathrm{CR})>0.70$ serta nilai variance extract (VE) $>0.50$. Berdasarkan tabel 1 dapat dilihat bahwa nilai CR untuk variabel pola asuh adalah sebesar $0.950>0.70$ serta nilai VE sebesar $0.906>0.50$, artinya bahwa model pengukuran sudah memiliki konsistensi internal (reliabel) yang baik dalam mengukur variabel pola asuh.

Variabel Religiusitas. Model pengukuran pada konstruk religiusitas dilakukan dengan mengukur indikatorindikatornya. Loading factors pada indikator harus lebih besar dari 0.5, karena loading factors indikator yang tinggi mengindikasikan indikator-indikator berkumpul pada variabel yang sama, dan menandakan indikator tersebut valid dan dapat membentuk variabel.

Berdasarkan pengukuran diketahui bahwa nilai standardized loading factors $(\Lambda)$ untuk indikator intelektualis dan ritualis kurang dari 0.5 sehingga dapat dikatakan bahwa indikator-indikator tersebut belum memiliki validitas yang baik dalam mengukur variabel religiusitas.

Pengujian reliabilitas ditunjukan oleh nilai construct reliability $(\mathrm{CR})>0.70$ serta nilai variance extract (VE) $>0.50$. Berdasarkan tabel 2 dapat dilihat bahwa nilai CR untuk variabel religiusitas adalah sebesar $0.953>0.70$ serta nilai VE sebesar $0.809>0.50$, artinya bahwa model pengukuran sudah memiliki konsistensi internal (reliabel) yang baik dalam mengukur variabel religiusitas.

Variabel Impulse Buying. Model pengukuran pada konstruk impulse buying dilakukan dengan mengukur indikatorindikatornya. Loading factors pada indikator harus lebih besar dari 0.5, karena loading factors indikator yang tinggi mengindikasikan indikator-indikator berkumpul pada variabel yang sama, dan 
menandakan indikator tersebut valid dan dapat membentuk variabel.

Berdasarkan pengukuran diketahui bahwa nilai standardized loading factors $(\Lambda)$ untuk indikator dimensi kognitif kurang dari 0.5 sehingga dapat dikatakan bahwa indikator-indikator tersebut belum memiliki validitas yang baik dalam mengukur variabel impulse buying.

Pengujian reliabilitas ditunjukan oleh nilai construct reliability $(\mathrm{CR})>0.70$ serta nilai variance extract (VE) $>0.50$. Berdasarkan tabel 3 dapat dilihat bahwa nilai CR untuk variabel impulse buying adalah sebesar $0.677<0.70$ serta nilai VE sebesar $0.547<0.50$, artinya bahwa model pengukuran belum memiliki konsistensi internal (reliabel) yang baik dalam mengukur variabel impulse buying.

\section{Kecocokan Model Struktural} (Structural Model Fit). Analisis model struktural berhubungan dengan evaluasi terhadap parameter-parameter yang menunjukan hubungan kausal atau pengaruh satu variabel laten terhadap variabel laten lainnya. Berikut ini disajikan gambar parameter estimasi standardized loading factor sebagai berikut.

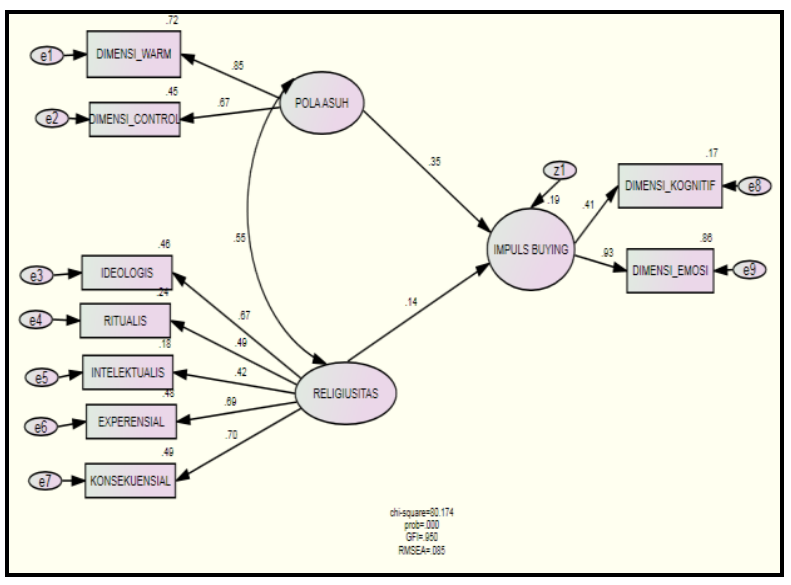

Gambar 1. Model Struktural pada Structural Equation Model Keseluruhan

Berdasarkan gambar di atas maka hasil estimasi parameter model struktural disajikan dalam tabel berikut ini:
Tabel 1

Ringkasan Hasil Estimasi Parameter Model

Struktural

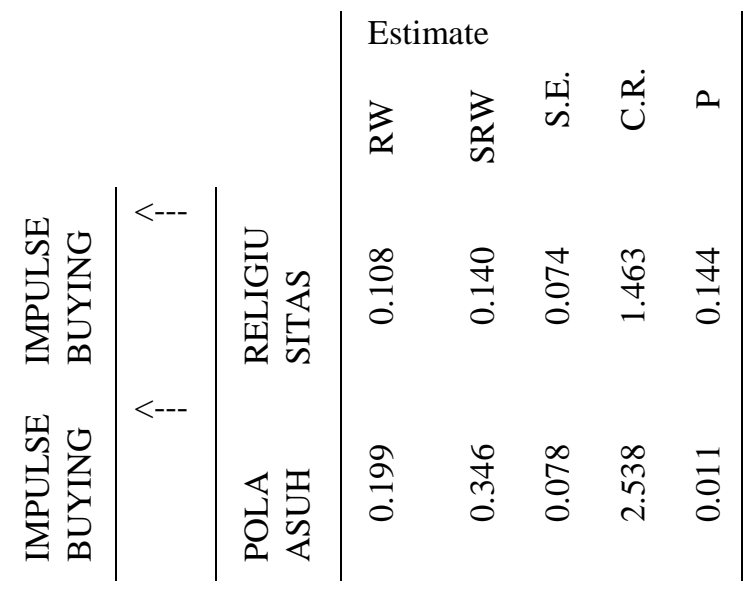

Berdasarkan tabel 1 dapat dilihat hasil uji keberartian terhadap masing-masing estimasi koefisien jalur ditemukan terdapat satu koefisien jalur secara statistik tidak signifikan yaitu koefisien jalur religiusitas terhadap impulse buying $\quad(P=0.144)$. Sehingga dengan tingkat kesalahan 5\% dapat disimpulkan bahwa religiusitas tidak berpengaruh terhadap impulse buying.

Kecocokan Keseluruhan Model (Overall Model Fit). Uji kecocokan keseluruhan model dilakukan untuk mengevaluasi secara umum derajat kecocokan atau Goodness of Fit (GOF) antara data dengan model. Hasil pengujian Overall Model Fit disajikan dalam tabel berikut ini:

Tabel 2

Pengujian Model Penelitian

\begin{tabular}{llcc}
\hline $\begin{array}{c}\text { Ukuran } \\
\text { Goodness of } \\
\text { Fit }\end{array}$ & $\begin{array}{c}\text { Hasil } \\
\text { Uji }\end{array}$ & $\begin{array}{c}\text { Cut } \\
\text { Off } \\
\text { Value }\end{array}$ & Keterangan \\
\hline $\begin{array}{l}\text { Chi-Square } \\
\text { (df=24) }\end{array}$ & 80.174 & $\begin{array}{c}\chi^{2} \text { hit }< \\
\chi^{2} \text { tabel } \\
(36.41)\end{array}$ & Tidak Fit \\
P-value & 0.0000 & $\geq 0.05$ & Tidak Fit \\
RMSEA & 0.085 & $\leq 0.08$ & Tidak Fit \\
NNFI (TLI) & 0.87 & $\geq 0.90$ & Tidak Fit \\
CFI & 0.914 & $\geq 0.90$ & Fit \\
GFI & 0.95 & $\geq 0.90$ & Fit \\
AGFI & 0.906 & $\geq 0.90$ & Fit \\
\hline
\end{tabular}


Uji kesesuaian model Structural Equation di atas menghasilkan $\mathrm{df}=24$ dengan nilai Chi-Square $80.174>$ ChiSquares $_{\text {tabel }}$ yakni 36.41, dan nilai P-value $0.000<0.05$ mengindikasikan model tidak fit. Begitupun dengan indeks kecocokan RMSEA sebesar 0.085 lebih besar dari cut off value (0.08), dan NNFI (TLI) sebesar 0.87 mempunyai nilai yang lebih kecil dari cut off value (0.90) sehingga menandakan model tidak fit dengan data. Akan tetapi jika dilihat dari nilai CFI sebesar 0.914, GFI sebesar 0.95, dan AGFI sebesar 0.906 mempunyai nilai yang lebih besar dari cut off value (0.90) berarti model fit dengan data. Secara keseluruhan dari ukuran goodness-of-fit dapat disimpulkan bahwa model secara keseluruhan tidak fit dengan data.

\section{Pembahasan}

Berdasarkan hasil data di atas, sebanyak 420 mahasiswa peserta pesantren calon sarjana tahun 2016 menjadi subjek penelitian. Setiap peserta mendapatkan 3 (tiga) angket yang sama yaitu Angket Pola Asuh, Angket Religiusitas, dan Angket Impulse Buying. Dari 420 mahasiswa, terpilih 328 mahasiswa yang termasuk ke dalam kriteria impulse buying. Selanjutnya dilakukan proses analisa statistika untuk melihat keeratan hubungan pola asuh dan religiusitas, lalu melihat signifikansi pengaruh kedua variabel tersebut terhadap impulse buying.

Berdasarkan data demografi yang diperoleh, yaitu dalam waktu satu minggu sebanyak $42 \%$ subjek menghabiskan uang Rp. 300.000,- s.d 600.000,- dan 19\% menghabiskan Rp. 600.000,- s.d Rp. 800.000, dengan uang saku yang diberikan orang tua $42 \%$ kurang dari 1 juta dan $49 \%$ antara 1 - 2 juta, artinya bahwa pada kenyataannya uang saku yang diberikan orang tua subjek akan habis pada minggu ke-3 atau ke-4 pada setiap bulannya. Padahal jika melihat dari data, uang yang mereka habiskan kebanyakan untuk membeli makanan (sebanyak 54\%).
Sementara jika melihat kebutuhan subjek sebagai mahasiswa, masih ada kebutuhan lainnya seperti untuk transportasi, buku acuan perkuliahan, praktikum, alat tulis dan bahkan untuk subjek mengerjakan tugastugas yang memerlukan alat-alat yang juga harus dibeli. Namun, dengan adanya data bahwa sebanyak $70 \%$ mahasiswa menggunakan motor sebagai alat transportasi, bisa dikatakan bahwa biaya yang mereka butuhkan untuk transportasi sudah teratasi. Namun, perlu diperdalam bagaimana mereka mendapatkan tambahan dana untuk sisa hari pada setiap bulannya. Beberapa dugaan dapat menjadi asumsi, yang pertama adalah subjek mempersepsi "uang saku" yang diberikan orang tua hanya untuk kebutuhan selama mereka melaksanakan aktivitas di luar rumah, dapat dipahami bahwa karena sebagian besar subjek masih tinggal dengan orang tua, sehingga manakala mereka mendapatkan kekurangan uang, mereka akan dengan mudah memintanya kepada orang tua, baik untuk kekurangan karena uang sakunya sudah habis sebelum waktunya atau untuk kebutuhan lain di luar dari uang saku yang diberikan.

Selanjutnya untuk variabel pola asuh, semua nilai standardized loading factors $(\Lambda)$ untuk masing-masing indikator lebih dari 0.5, baik untuk dimensi warm maupun dimensi control. Namun untuk skor dimensi warm lebih tinggi $(0,851)$ dibandingkan dimensi control $(0,67)$. Hal ini berarti subjek menghayati bahwa orang tua memberikan kehangatan dan mendukung mereka. Menurut Baumrind (dalam Sigelman, 2003) orang tua dihayati dapat memenuhi setiap kebutuhan anak, empati pada perasaan anak, berupaya menyejahterakan anak, meluangkan waktu untuk melakukan kegiatan bersama, memberikan pujian manakala mereka berprestasi atau memenuhi kebutuhan anak serta dapat menerima bagaimana pun kondisi anak sehingga mereka responsif terhadap segala sesuatu yang terjadi pada anak. Sekalipun mereka juga menghayati 
bahwa orang tua juga menetapkan kontrol, seperti menetapkan aturan berupa pembatasan, tuntutan, keketatan aturan, keterlibatan peran sebagai orang tua, namun mereka lebih mengahayati bahwa kehangatan (warm) lebih bermakna bagi mereka. Seperti halnya pada mahasiswa UNISBA yang menjadi sampel penelitian, mereka menghayati bahwa orang tua perhatian terhadap mereka, berupa memenuhi seluruh kebutuhan mereka, meskipun tidak berkaitan secara langsung dengan kebutuhan perkuliahan. Hal ini terlihat dari tersedianya fasilitas yang mendukung aktivitas mereka, memberikan kendaraan, uang saku, longgar dalam pengawasan, karena anggapannya bahwa mereka sudah dewasa sehingga mampu mengambil keputusan sendiri, meskipun tingkat pengawasan dari orang tuanya pun tidak kuat. Dalam hal ini ketika mereka melakukan pembelanjaan diluar kebutuhan, orang tua tidak memberikan pemahaman bahwa perbuatan tersebut akan menimbulkan konsekuensi yang negatif, seperti mubadzir karena sebetulnya mereka tidak membutuhkan barang tersebut.

Variabel religiusitas diketahui memiliki nilai standardized loading factors $(\Lambda)$ untuk dimensi intelektualis dan dimensi ritualis kurang dari 0,5. Sementara untuk dimensi konsekuensial, dimensi eksperiensial dan dimensi ideologis mendapat nilai standardized loading factors $(\Lambda)$ diatas 0,5 . Artinya subjek menilai penghayatan religiusitasnya didasari bahwa sebagai orang yang beragama Islam perlunya untuk beramal shaleh sebagai bentuk pengabdian kepada Allah Swt., karena dengan demikian ia akan mengalami ketenangan batin dan menemukan makna hidup. Penghayatan religiusitas akan semakin meningkat manakala ada akibat yang mereka alami ketika mereka tidak menjalankan ajaran agama atau ketika mereka menjalankan kehidupan yang dipersepsi sebagai cobaan atau ujian. Dari hasil yang diperoleh, penghayatan religiusitas tidak serta merta mereka rasakan dengan menjalankan ritualitas dari ajaran agama secara intens. Hal tersebut tampaknya karena pada dimensi intelektualisnya yang rendah, sehingga mereka tidak begitu memperdalam ajaran agama yang harus mereka jalani. Pengetahuan keagamaan mahasiswa baru sebatas amalan shaleh yang berkaitan dengan ritual-ritual, belum sampai pada pemahaman lebih mendalam, seperti misalnya ketika mereka melakukan perbuatan boros, perbuatan yang sia-sia berarti mereka telah berdosa, sama berdosanya dengan ketika mereka tidak melakukan shalat. Mereka dapat memahami bahwa suatu perilaku dapat dikatakan tidak baik, jika mereka merasakan dampak langsung akibat perbuatan mereka tersebut. Dalam hal ini, ketika mereka berbelanja dengan spontan tanpa perencanaan untuk suatu hal yang tidak dibutuhkan, tidak akan menimbulkan dampak yang negatif. Terlebih lagi diperkuat dengan pendidikan orang tua yang meyakini bahwa dengan memberikan fasilitas, seperti uang saku yang bebas digunakan apa saja tanpa mengontrolnya adalah bentuk perhatian orang tua.

Pada variabel impulse buying, nilai standardized loading factors $(\Lambda)$ untuk dimensi emosi mendapatkan nilai lebih dari 0.5. Hal tersebut menjelaskan bahwa dalam melakukan aktivitas berbelanja, subjek lebih terdorong karena faktor emosi daripada faktor kognitif. Artinya bahwa dalam melakukan aktivitas berbelanja, subjek melakukan secara spontan, disertai dengan dorongan yang hebat. Hal tersebut juga dipertahankan karena subjek merasa senang setelah melakukan aktivitas berbelanja sehingga tampaknya mengabaikan konsekuensi dari kegiatan berbelanja yang tidak terkendali tersebut.

Selanjutnya jika berdasarkan hasil estimasi parameter Model Struktural dapat dilihat bahwa baik variabel religiusitas maupun variabel pola asuh memiliki pengaruh yang tidak signifikan terhadap impulse buying. Terdapat beberapa hal 
yang menarik, pertama yaitu sekalipun tidak memiliki pengaruh, namun masingmasing variabel memperlihatkan skor yang tinggi yang dimiliki oleh subjek. Hal ini berarti bahwa hampir keseluruhan subjek menunjukan perilaku impulse buying, yang disertai dengan pola asuh dan religiusitas yang tinggi. Kedua, variabel pola asuh memperoleh skor yang lebih tinggi dibandingkan religiusitas terhadap impulse buying, sehingga dapat diasumsikan bahwa pola asuh memiliki kontribusi terhadap munculnya perilaku impulse buying.

Penjelasan dari kedua data tersebut, adalah sebagai berikut: Pertama, bahwa subjek yang memiliki religiusitas tinggi ternyata menunjukan perilaku impulse buying yang tinggi pula. Terdapat tiga dimensi yang memperoleh skor tinggi pada variabel religiusitas yaitu dimensi konsekuensial, dimensi ideologis, dan dimensi eksperiensial. Bila dihubungkan dengan impulse buying, diperoleh beberapa penjelasan yang dapat dilihat dari data demografi bahwa setiap subjek tidak memiliki kesulitan finansial, sekalipun mereka mendapatkan uang saku namun manakala mereka kekurangan, namun karena mereka masih tinggal dengan orang tua, maka mereka akan lebih mudah untuk meminta. Subjek tidak menghayati bahwa habisnya uang di tengah bulan disebabkan perilaku berbelanja mereka yang kurang terkontrol, karena uang yang mereka habiskan digunakan untuk membeli makanan dan pakaian, yang mana keduanya seolah-olah mereka pahami sebagai kebutuhan dasar. Dengan demikian kosekuensi dari perilaku impulse buying sebagai perilaku yang dipandang berlebihan dalam ajaran Islam belum mereka rasakan. Hal tersebut terjadi dimungkinkan karena bagi mereka antara religiusitas dengan perilaku berbelanja tidak ada keterkaitan. Dengan penanaman agama yang mereka peroleh dari orang tua, sekolah/perguruan tinggi dan tempat-tempat mempelajari agama, tampaknya belum cukup mampu menjadi kendali dari impulse buying, karena sekalipun religiusitasnya tinggi, kenyataannya perilaku impulse buying pun masih tinggi.

Kedua, pola asuh memiliki kontribusi terhadap perilaku impulse buying, sekalipun sama-sama tidak signifikan. Artinya dapat dilihat bahwa pola asuh dihayati sebagai variabel yang mempengaruhi impulse buying. Jika melihat data demografi, hampir secara keseluruhan subjek masih tinggal dengan orang tua, artinya bahwa mereka masih dapat dengan mudah memperoleh segala sesuatu yang mereka butuhkan sehari-hari. Subjek juga mendapatkan fasilitas transportasi yang mempermudah mobilisasi, $70 \%$ menggunakan motor. Hal ini menunjukan bahwa pola asuh "warm" yang dipersepsi oleh subjek merupakan pola asuh yang membuat subjek merasa diperhatikan dan diberikan fasilitas sesuai dengan yang diinginkan subjek. Sehingga uang saku yang diberikan oleh orang tua jika habis sebelum waktunya, akan mudah mereka minta kembali. Pola asuh yang memudahkan subjek mendapatkan fasilitas membuat subjek menjadi kurang mengendalikan perilaku impulse buying. Namun, subjek tidak menyadari bahwa hal tersebut merupakan perilaku yang tidak terkendali dan berkonsekuensi, karena subjek belum merasakan atau mengalami konsekuensi negatif dari perilaku berbelanja yang tidak terkendali.

\section{Simpulan}

\section{Simpulan dan Saran}

Dari 420 peserta Pesantren Calon Sarjana Unisba, terdapat 328 peserta yang menunjukan perilaku impulse buying. Variabel pola asuh dan variabel religiusitas tidak memiliki pengaruh yang signifikan terhadap variabel impulse buying.

Pada variabel religiusitas diperoleh nilai yang tinggi pada dimensi konsekuensial, dimensi ideologis dan dimensi eksperiensial. Pada variabel pola asuh mendapat nilai yang tinggi pada dimensi warm. Pada variabel impulse 
buying, mendapat nilai yang tinggi pada dimensi emosi.

\section{Saran}

Meskipun pola asuh dan religiusitas pada penelitian ini tidak mempunyai pengaruh yang signifikan terhadap perilaku impulse buying, namun berdasarkan temuan pada penelitian ini bahwa sebagian besar mahasiswa termasuk pada kategori impulse buying. Orang tua yang memberikan pembelajaran bahwa dengan berbelanja, akan menimbulkan perasaan senang, meskipun sifatnya spontan dan kurang terarah, hendaknya mulai memikirkan kembali pemahaman seperti ini disebabkan ketika perilaku tersebut menjadi semakin tidak terkontrol akan mengarah pada gangguan yang akibatnya akan jauh lebih besar daripada kenikmatan sesaat setelah berbelanja.

Mengingat pembelajaran agama sebagian besar didapat di keluarga, maka proses internalisasi di keluarga harus dilakukan. Tidak sekedar memberikan pengetahuan saja bahwa kita tidak boleh boros dan melakukan perbuatan yang siasia, namun menumbuhkan pemahaman dan penghayatan, mengenai manfaat kebiasaan hidup yang baik sesuai tuntunan agama, sehingga penghayatan tidak hanya terjadi saat individu merasakan konsekuensi langsung dari apa yang dilakukannya.

\section{Daftar Pustaka}

Ancok, Djamaludin \& Suroso, Fuad Nashori. (1995). Psikologi Islami. Solusi Islam atas Problem-problem Psikologi, Yogyakarta: Penerbit Pustaka Pelajar.

Dwarawati, Dinda. (2015). Pengaruh Konseling Kelompok SelfRegulation terhadap Peningkatan Self-Regulation pada Penderita Compulsive Buying di Bandung. Tesis. Bandung: Magister Profesi Psikologi Unisba.
Engel, J., Blackwell, R. (1995). Consumer Behavior, Chicago, IL: Dryden Press.

Loudon, D. L., Bitta, A. J. (1993). Consumer Behavior Concept and Application 4th ed., Singapore: McGraw Hill.

Nugrahawati, Eni. (2014) Hubungan antara Religiusitas dengan Impulse Buying pada Mahasiswa Fakultas Kedokteran Universitas Islam Bandung, SnaPP 2014, a, (P2ULPPM) Unisba, ISSN 2089-3590, Volume 4. No. 1, hal. 209-216.

O'Guinn, Thomas C. \& Faber, Ronald J. 1989. Compulsive Buying: A Phenomenological Exploration, Journal of Consumer Research.

Rook, Dennis W. 1987. The Buying Impulse, Journal of Consumer Research, 14 (September), 189-199.

Sigelman, C. K. \& Rider, E. A. (2003). Life-Span Human Development 4th ed., United States America: Wadsworth Thomson Learning.

Verplanken, B., Herabadi, A. G. 2001. Individual Differences in Impulse Buying Tendency: Feeling and no Thinking, European Journal of Personality, John Wiley \& Sons, Ltd.

www.pustaka.unpad.ac.id 
Psympathic, Jurnal Ilmiah Psikologi Desember 2016, Vol. 3, No. 2, Hal: 235 - 248 